\title{
Vztah tělesného složení a funkčních parametrů u rekreačních triatlonistů
}

\section{The relationship of body composition and functional parameters in recreational triathlonists}

\author{
Ivana Kinkorová, Jan Heller, Pavel Vodička, Klára Coufalová
}

Fakulta tělesné výchovy a sportu Univerzity Karlovy v Praze

\begin{abstract}
Abstrakt:
Cílem studie bylo zhodnotit parametry tělesného složení a jejich vztah $\mathrm{k}$ funkčním parametrüm u rekreačních

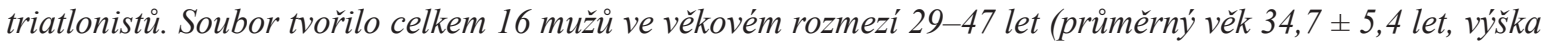
$181,2 \pm 4,7 \mathrm{~cm}$, hmotnost 79,3 $\pm 5,6 \mathrm{~kg}, \mathrm{BMI} 24,4 \pm 2,0 \mathrm{~kg} \cdot \mathrm{m}^{-2}$, tělesný tuk 15,5 $\pm 3,6 \%, F F M$ 67,0 \pm 3,9 kg, $\mathrm{VO}_{2}$

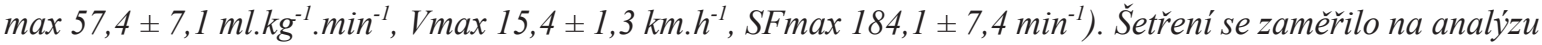
tělesného složení (BIA In Body 3.0) a aerobní zdatnost ( $\mathrm{VO}_{2}$ max, Vmax, SF max). Nalezli jsme významný vztah $V_{2}$ max a procenta tělesného tuku $(r=-0,78, p<0,05)$, Vmax a procenta tělesného tuku $(r=-0,534, p<$ $0,05)$.
\end{abstract}

\begin{abstract}
:
The aim of this study was to evaluate the body composition parameters and their relationship to functional parameters in recreational triathlonists. The group consisted of 16 men ranging in age from $29-47$ years (mean age - 34,7 \pm 5,4 years, height $-181,2 \pm 4,7 \mathrm{~cm}$, weight $-79,3 \pm 5,6 \mathrm{~kg}, \mathrm{BMI}-24,4 \pm 2,0 \mathrm{~kg} . \mathrm{m}^{-2}$, body fat $-15,5 \pm 3,6 \%, F F M-67,0 \pm 3,9 \mathrm{~kg}, V_{2} \max -57,4 \pm 7,1 \mathrm{ml} \cdot \mathrm{kg}^{-1} \cdot \mathrm{min}^{-1}, V \max -15,4 \pm 1,3 \mathrm{~km} \cdot \mathrm{h}^{-1}$, HRmax - 184,1 \pm 7,4 $\left.\mathrm{min}^{-1}\right)$. The investigation was focused on the analysis of body body compostion (BIA, In Body 3.0) and aerobic capacity $\left(\mathrm{VO}_{2}\right.$ max, $\mathrm{Vmax}, \mathrm{SF}$ max). We found a significant relationship of $\mathrm{VO}_{2}$ max and percent of body fat $(r=-0,78, p<0,05)$, Vmax and percent of body fat $(r=-0,534, p<0,05)$.
\end{abstract}

Klíčová slova: rekreační pohybová aktivita, tělesné složeni, funkční zátěžové parametry

Key words: recreational physical activity, body composition, functional load parameters

Tato studie vznikla s podporou projektu PRVOUK P38.

\section{ÚVOD}

Měnící se životní styl jedince, ale i různých sociálních skupin, vede ke zhoršování předpokladů pro pohybové aktivity a z toho vyplývající zhoršování kvality života. Průvodním jevem je snížená aerobní zdatnost, snížení schopnosti regenerace člověka po pracovním zatížení, snižující se možnost využití stále rostoucího objemu volného času a zvýšené riziko výskytu řady onemocnění, které mají př́icinu v hypokinezi (Bunc, 2007). Výsledky většiny současných studií se shodují v tom, že k vzrůstajícímu výskytu nadváhy nebo dokonce obezity dochází jednoznačně v důsledku současného životního stylu a ta se pak stává celosvětovým problémem. Epidemie nadváhy a obezity, která je způsobena zejména nerovnováhou mezi nedostatečnou fyzickou aktivitou a nadměrným celkovým energetickým př́imem, způsobuje celou řadu závažných zdravotních, klinických a ekonomických problémů v moderní společnosti. Zvyšuje se především riziko výskytu kardiovaskulárních onemocnění (ateroskleróza, arteriální hypertenze, ischemická choroba srdeční (ICHS), mozková mrtvice), vysoké hladiny triglyceridů (TG) a LDL cholesterolu v krvi, postprandiální hyperinzulinémie a sacharidové intolerance, diabetes mellitus II. typu, osteoporózy, zhoubných novotvarů, deprese (Wei et al., 1999). 
Tělesné složení, které je jedním z nejdůležitějších ukazatelů vývojového stupně v průběhu ontogeneze, ukazatelem úrovně zdraví, tělesné zdatnosti, výkonnosti, ale i stavu výživy jedince, je poměrně významně individuálně ovlivněno věkem, pohlavím, stavem výživy, pohybovou aktivitou a individuální variabilitou (Pařízková, 1998; Dlouhá et al., 1998). BMI (Body mass index), který patří mezi kvantitativní klinické ukazatele složení těla, však může nepřesně interpretovat skutečné tělesné složení určitých skupin jedinců. Při srovnání elitních a rekreačních sportovců se můžeme obvykle setkat s vyšší tělesnou hmotností, která je však dána vyšším množstvím svalové hmoty. Obecně lze říci, že vytrvalostní sportovci mají nižší BMI než jedinci zabývající se aktivitami, které vyžadují velké množství svalové hmoty pro anaerobní činnost (Andreoli et al., 2003).

Pohybové aktivity jsou významným komplexním prostředkem ovlivňování člověka. Pravidelně prováděná pohybová aktivita, označovaná jako hlavní prvek zdravého životního stylu, má nezastupitelný význam nejen v primární, ale i sekundární a terciální prevenci (Stejskal, 2013). Způsobuje četné adaptivní změny, které vedou $\mathrm{k}$ účinnějšímu transportu kyslíku do svalu, zlepšení využití lipidů místo sacharidů. Redukce tukové tkáně dále pak zlepšuje mechanickou účinnost pohybů. V posledních desetiletích podstatně klesá množství pohybu, i když genetické vybavení jedince se nemění. Potřeba pohybu zůstává, ale skutečná realizace znamená deficit a z něj vyplývá řada komplikací. Pravidelná pohybová aktivita i přirozená (obvyklá, habituální) je spolu s přiměřeným energetickým příjmem nejlepším, nejbezpečnějším ekonomicky nenákladným preventivním nebo v další řadě léčebným prostředkem většiny civilizačních onemocnění (Bunc, 2006). Zdravotní benefity pohybové aktivity jsou závislé na frekvenci, intenzitě a délce trvání aktivity (Bouchard, 2000). Řada klinických studií uvádí, že pohybová aktivita střední intenzity $30 \mathrm{~min}$. denně snižuje riziko ischemické choroby srdeční (ICHS) o 50\%, riziko hypertenze, diabetu, rakoviny tlustého střeva o $30 \%$, dále pak pozitivně ovlivňuje regulaci tělesné hmotnosti (snížení adipozity), inzulínovou rezistenci, pozitivně působí na dyslipidémii a fibrinolytické a endoteliální funkce (Bassuk \& Manson, 2005).

V poslední době se staly velmi populárními $1 / 2$ maraton, maraton a vícedisciplinové vytrvalostní sporty. Vytrvalostní víceboje patři mezi mladá sportovní odvětví a historicky prvním a zároveň nejvýznamnějším je triatlon, který se skládá z jednotlivých disciplín - plavání, cyklistika a běh (Suriano \& Bishop, 2010). Pro nejširší veřejnost jsou pořádány pravidelné závody v kratších objemech, které jsou často prováděny i nezávodní formou. Hlavní rozmanitost triatlonu spočívá především v rozdílné vzdálenosti v jednotlivých disciplínách, což vytváří specifické technické, fyziologické a nutriční aspekty pro sportovce (Bentley et al., 2008). Fyziologické změny, ke kterým dochází v průběhu tréninku či závodu, se prakticky odráží ve všech systémech těla a projeví se především v parametrech jako jsou aerobní kapacita (měřeno jako maximální spotřeba kyslíku, $\mathrm{VO}_{2} \max$ ), ekonomika pohybu (submaximální $\left.\mathrm{VO}_{2}\right)$ a frakční využití maximální kapacity $\left(\% \mathrm{VO}_{2} \max \right)(\mathrm{O}$ Toole \& Douglas, 1995).

Je třeba zdůraznit, že nejen př́padný vztah rizikových faktorů a výskytu výše zmiňovaných onemocnění, ale i př́padný vztah pohybové aktivity a uváděných parametrů je dán individuálně.

Cílem našeho sledování byla analýza jednotlivých parametrů tělesného složení a jejich případný vztah k parametrům aerobní zdatnosti u rekreačních triatlonistů $(n=16)$ ve věkovém rozmezí 29 - 47 let. Pro pohybově aktivní jedince může být sledování změn nejen v jednotlivých parametrech tělesného složení, ale i ve funkčních zátěžových parametrech významným ukazatelem vlivu pohybové aktivity.

\section{METODIKA}

\section{Soubor}

Sledovaný soubor rekreačních triatlonistů tvořilo celkem 16 mužů, členů TRISPORTTEAMu, ve věkovém

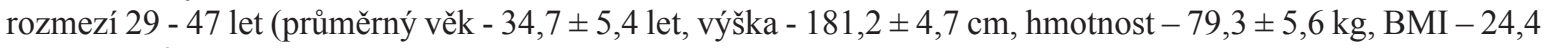
$\left.\pm 2,0 \mathrm{~kg} \cdot \mathrm{m}^{-2}\right)$. Do šetření byli zahrnuti jedinci, kteří se věnovali triatlonu v průměru $4-5$ let s přibližně stejnou týdenní charakteristikou pohybové aktivity (plavání 3x 30 min./týden, běh 2 x $5-7$ km/týden, 2 - 3 x 30 - 50 km/týden). Testování proběhlo jednorázově v prostorách Biomedicínské laboratoře UK FTVS.

\section{Použité metody}

Ze základních antropometrických parametrů byly měřeny tělesná výška $(\mathrm{cm})$ a tělesná hmotnost $(\mathrm{kg})$. Tělesná výška $(\mathrm{cm})$ byla stanovena pomocí antropometru s přesností na $0,1 \mathrm{~cm}$. Tělesná hmotnost $(\mathrm{kg})$ byla měřena pomocí osobní mechanické váhy s přesností na $0,1 \mathrm{~kg}$. Byl stanoven index BMI $\left(\mathrm{kg} \cdot \mathrm{m}^{-2}\right)$. 
K analýze tělesného složení byl použit multifrekvenční přístroj BIA In Body 3.0 (Biospace Co.), který pracuje s frekvencemi $5,50,250,500 \mathrm{kHz}$ v tetrapolární konfiguraci elektrod. Sledovány byly především následující parametry: celková tělesná voda (TBW), extracelulární $(\mathrm{ECW})$ a intracelulární $(\mathrm{ECW})$ voda, tukuprostá hmota (FFM), tělesný tuk (FM), množství buněčné hmoty (BCM), segmentární distribuce tekutin. Pro stanovení jednotlivých parametrů složení těla byl použit software s predikčními rovnicemi, který je součástí př́ístroje.

Měření antropometrických parametrů a obsluhu přístroje BIA In Body 3.0 prováděla jedna osoba z důvodu minimalizace chyby. Při sběru všech dat byly zajištěny stejné objektivní podmínky.

Srdeční frekvence byla kontinuálně monitorována telemetrií o krátkém dosahu (Sport-Tester PE 4000, Polar Electro, Finsko). Maximální spotřeba $\mathrm{O}_{2}\left(\mathrm{VO}_{2} \max \right)$ byla stanovena zátěžovým testem na běhacím koberci, proband absolvoval dvě čtyřminutové rozcvičky na nulovém sklonu koberce o rychlostech 9 a $11 \mathrm{~km} \cdot \mathrm{h}^{-1}$. Vlastní maximální test byl proveden na $5 \%$ sklonu a rychlost byla zvyšována počítačem (ramp-test) s nárůstem o 200 $\mathrm{m} \cdot \mathrm{h}^{-1}$ každých $12 \mathrm{~s}$, s počáteční rychlostí $10 \mathrm{~km} \cdot \mathrm{h}^{-1}$. Spotřeba kyslíku byla stanovena $\mathrm{v}$ otevřeném systému pomocí analyzátorů $\mathrm{O}_{2}$ a $\mathrm{CO}_{2}$ (SensorMedics, Velká Británie) a průtokoměru K 520, KL Engineering Co. (USA). Rozhodujícím kritériem pro $\mathrm{VO}_{2}$ max bylo dosažení plató v hodnotách $\mathrm{VO}_{2}$ a maximální hodnoty byly určeny ze čtyř nejvyšších po sobě následujících 15 -s hodnot spotřeby $\mathrm{O}_{2}$.

\section{Statistické zpracování}

$\mathrm{K}$ analýze dat a jejich statistickému zpracování jsme použili programy SPSS a Microsoft Excel. Pro popis souboru byly využity základní statistické charakteristiky (aritmetický průměr, směrodatná odchylka). Pro zhodnocení významnosti rozdílů mezi horními a dolními končetinami jsme použili párový t-test, významnost rozdílu byla posuzována na hladině významnosti $\alpha=0,05$. Pro posouzení věcné (praktické) významnosti byl použit koeficient „effect size“ $\left(\omega^{2}\right)$. Za věcně významný rozdíl jsme považovali hodnoty $\omega^{2} \geq 0,1$. Př́ipadný vztah parametrů aerobní zdatnosti a parametrů tělesného složení byl posuzován pomocí Pearsonova korelačního koeficientu (r) na hladině významnosti $\alpha=0,05, \alpha=0,01$.

\section{Výsledky}

Průměrné hodnoty základních antropometrických charakteristik a jednotlivých parametrů z analýzy tělesného složení jsou uvedeny v Tab. 1. 
Tab. 1: Základních antropometrické charakteristiky a jednotlivé parametry z analýzy tělesného složení BIA (InBody 3.0) u rekreačnich triatlonistì $(n=16)$.

Data jsou uváděna ve tvaru aritmetický průměr \pm směrodatná odchylka

\begin{tabular}{|c|c|c|c|}
\hline \multirow{2}{*}{\multicolumn{2}{|c|}{ Věk (let) }} & průměr $\pm \mathrm{SD}$ & $\min -\max$ \\
\hline & & $34,7 \pm 5,4$ & $29,0-47,0$ \\
\hline \multicolumn{2}{|c|}{ Tělesná hmotnost (kg) } & $79,3 \pm 5,6$ & $70,0-92,2$ \\
\hline \multicolumn{2}{|c|}{ Tělesná výška (cm) } & $181,2 \pm 4,7$ & $173,4-187,7$ \\
\hline \multicolumn{2}{|c|}{ BMI (kg.m $\left.{ }^{-2}\right)$} & $24,4 \pm 2,0$ & $21,5-28,8$ \\
\hline \multicolumn{2}{|c|}{ TBW (1) } & $49,5 \pm 2,9$ & $43,4-53,7$ \\
\hline \multicolumn{2}{|l|}{ ICW (1) } & $32,7 \pm 2,6$ & $25,2-36,7$ \\
\hline \multicolumn{2}{|l|}{ ECW (1) } & $16,1 \pm 1,3$ & $13,4-18,1$ \\
\hline \multicolumn{2}{|l|}{ PM (kg) } & $13,3 \pm 0,7$ & $12,0-14,7$ \\
\hline \multicolumn{2}{|l|}{$\mathrm{BM}(\mathrm{kg})$} & $4,17 \pm 0,21$ & $3,75-4,47$ \\
\hline \multicolumn{2}{|l|}{ MM (kg) } & $62,8 \pm 3,7$ & $55,4-68,2$ \\
\hline \multicolumn{2}{|c|}{ FFM (kg) } & $67,0 \pm 3,9$ & $59,2-72,7$ \\
\hline \multicolumn{2}{|c|}{ FM $(\%)$} & $15,5 \pm 3,6$ & $11,2-21,9$ \\
\hline \multicolumn{2}{|c|}{$\mathrm{BCM}(\mathrm{kg})$} & $46,7 \pm 2,5$ & $42,1-51,3$ \\
\hline \multirow{6}{*}{ 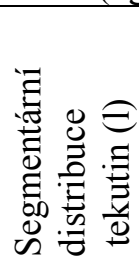 } & RA & $3,01 \pm 0,23$ & $2,51-3,33$ \\
\hline & LA & $2,95 \pm 0,22$ & $2,44-3,31$ \\
\hline & $\mathrm{T}$ & $22,8 \pm 1,2$ & $20,3-24,8$ \\
\hline & $\mathrm{RL}$ & $8,29 \pm 0,64$ & $7,07-9,37$ \\
\hline & LL & $8,28 \pm 0,67$ & $6,98-9,41$ \\
\hline & Edema exam & $0,325 \pm 0,01$ & $0,308-0,344$ \\
\hline
\end{tabular}

Legenda:

TBW-celková tělesná voda (l), ICW-intracelulární voda (l), ECW-extracelulární voda (l), PM-bílkovinová hmota (kg), BM - kostni hmota (kg), MM - svalová hmota (kg), FFM - tukuprostá hmota (kg), FM - tuková hmota (\%), BCM - množství buněčné hmoty (kg), RA-objem tekutin v pravé horni končetině (l), LA - objem tekutin v levé horní končetině (l), $T$-objem tekutin v trupu (l), $R L$-objem tekutin v pravé dolni tekutině (l), $L L$ - objem tekutin v levé dolní končetinè (l), Edema exam (index retence vody) - poměr ECW/TBW, ukazatel otoků

Průměrná hodnota BMI $\left(\mathrm{kg} \cdot \mathrm{m}^{-2}\right)$ sledovaného souboru 24,4 $\pm 2,0 \mathrm{~kg} \cdot \mathrm{m}^{-2}$ odpovídá doporučenému rozmezí pro optimální tělesnou hmotnost u běžné populace $\left(B M I=20-24,9 \mathrm{~kg} \cdot \mathrm{m}^{-2}, \mathrm{WHO}, 2013\right)$. Průměrné hodnoty celkové tělesné vody (TBW) byly 49,5 $\pm 2,9$ 1, což odpovídá hydrataci 62,4 \%. Hodnoty intracelulární vody (ICW) byly v průměru 32,7 $\pm 2,61$ (66,1 \%). Extracelulární voda $(\mathrm{ECW})$ tvořila v průměru 16,1 $\pm 1,31$ (32,5 $\%)$. Množství tělesného tuku bylo v průměru 15,5 $\pm 3,6 \%$, což odpovídá populačním normám.

Ve sledované skupině uvedlo $100 \%$ probandů dominantní PHK. Dominanci PDK uvedlo 10 probandů (tj. 62,5 \% probandů) a dominanci LDK 6 probandů (tj. 37,5 \% probandů). Při sledování rozložení vody na horních končetinách jsme zaznamenali průměrné hodnoty 3,01 $\pm 0,231$ na PHK a 2,95 $\pm 0,221$ na LHK. Tento rozdíl byl statisticky $(\mathrm{t}(16)=3,26 ; \mathrm{p}<0,05)$ i věcně $\left(\omega^{2}=0,38\right)$ významný. Na dolních končetinách jsme zaznamenali průměrné hodnoty $8,29 \pm 0,641$ na PDK a $8,28 \pm 0,671$ na LDK. Tento rozdíl nebyl statisticky $(\mathrm{t}(16)=0,202$; p > 0,05$)$ ani věcně $\left(\omega^{2}=0,06\right)$ významný. Průměrné hodnoty Edema exam (index retence vody) se pohybovaly $\mathrm{v}$ doporučeném rozmezí $0,30-0,35$, což neukazovalo na př́ípadný problém s otoky u žádného z probandů. 
Tab. 2: Průměrné hodnoty parametrů z maximálního zátěžového testu u rekreačních triatlonistů

$(n=16)$. Data jsou uváděna ve tvaru aritmetický průměr \pm směrodatná odchylka.

\begin{tabular}{|l|l|l|}
\hline & průměr $\pm \mathrm{SD}$ & $\min -\max$ \\
\hline $\mathrm{VO}_{2} \max \left(\mathrm{ml} \cdot \mathrm{kg}^{-1} \cdot \mathrm{min}^{-1}\right)$ & $57,4 \pm 7,1$ & $43,2-69,6$ \\
\hline $\mathrm{Vmax}\left(\mathrm{km} \cdot \mathrm{h}^{-1}\right.$, sklon 5\%) & $15,4 \pm 1,3$ & $13,0-17,5$ \\
\hline SF max $\left(\mathrm{min}^{-1}\right)$ & $184,1 \pm 7,4$ & $170,0-196,0$ \\
\hline
\end{tabular}

Úroveň maximální spotřeby kyslíku $\left(\mathrm{VO}_{2} \max \right)$ stanovené v testu na běhacím koberci převyšují populační normy (39,3 $\mathrm{ml} \cdot \mathrm{kg}^{-1} \cdot \mathrm{min}^{-1}$, Seliger a Bartůněk 1976, Máček a Máčková 1996) a odpovídají úrovni maximálního výkonu udávané u triatlonistů rekreační výkonnosti obdobného věku (56-58 $\mathrm{ml}^{\mathrm{kg}} \mathrm{kg}^{-1} \cdot \mathrm{min}^{-1}$, Holly et al. 1986 , Slattery et al. 2006).

\section{DISKUSE}

Informace o tělesném složení mohou být indikátorem nutričního stavu jedince, ale také mohou podat informaci o aktuální homeostáze tekutin v těle. BMI (Body mass index) patří mezi kvantitativní klinické ukazatele složení těla. Může však nepřesně interpretovat skutečné tělesné složení určitých skupin jedinců. Při srovnání elitních a rekreačních sportovců se můžeme obvykle setkat s vyšší tělesnou hmotností, která je však dána vyšším množstvím svalové hmoty a kostní hmoty a nízkého zastoupení tukové hmoty. Obecně lze říci, že vytrvalostní sportovci mají nižší BMI než jedinci zabývající se aktivitami, které vyžadují velké množství svalové hmoty pro anaerobní činnost (Andreoli et al., 2003). Průměrná hodnota BMI $\left(\mathrm{kg}^{\left.-\mathrm{m}^{-2}\right)}\right.$ sledovaného souboru 24,4 $\pm 2,0 \mathrm{~kg} \cdot \mathrm{m}^{-2}$ (Tab. 1.) odpovídá doporučenému rozmezí pro normální tělesnou hmotnost u běžné populace $\left(\mathrm{BMI}=20-24,9 \mathrm{~kg} \cdot \mathrm{m}^{-2}, \mathrm{WHO}, 2013\right)$.

Celková tělesná voda (TBW), která patří mezi jednu z nejvýznamnějších komponent složení těla, ovlivňuje především denzitu tukuprosté hmoty, ale tím i odhad tělesného tuku (\%). Průměrné hodnoty celkové tělesné vody (TBW) byly 49,5 $\pm 2,9$, což odpovídá hydrataci 62,4 \%. Hodnoty intracelulární vody (ICW) byly v průměru 32,7 $\pm 2,61(66,1 \%)$. Extracelulární voda $(\mathrm{ECW})$ tvořila v průměru $16,1 \pm 1,31, \mathrm{j}$. 32,5 \% (Tab. 1.). Ve sportovní praxi je výhodné sledovat rozložení TBW v jednotlivých tělesných segmentech, kde se v distribuci při porovnání pravolevé poloviny těla projeví nestejnoměrné zatěžování pravých a levých končetin, jednostranná preference končetin při tréninku a jednostranné zatěžování, které může následně vést ke vzniku svalových dysbalancí a funkčních poruch pohybového systému (Skorocká et al., 2004). Řada studií (Kichul et al., 1997, 2001; Roche et al., 1996) ukazuje, že zvýšený podíl tekutiny v daném segmentu je projevem vyššího zastoupení svalové hmoty v segmentu. Při sledování rozložení tekutin na horních končetinách jsme zaznamenali průměrné hodnoty 3,01 $\pm 0,231$ na PHK a 2,95 $\pm 0,221$ na LHK. Tento rozdíl byl statisticky $(\mathrm{t}(16)$ $=3,26 ; \mathrm{p}<0,05)$ i věcně $\left(\omega^{2}=0,38\right)$ významný. Na dolních končetinách jsme zaznamenali průměrné hodnoty $8,29 \pm 0,641$ na PDK a 8,28 $\pm 0,671$ na LDK. Tento rozdíl nebyl statisticky $(\mathrm{t}(16)=0,202 ; \mathrm{p}>0,05)$ ani věcně $\left(\omega^{2}=0,06\right)$ významný. Průměrné hodnoty Edema exam (index retence vody) se pohybovaly v doporučeném rozmezí $0,30-0,35$, což neukazovalo na př́ípadný problém s otoky u žádného z probandů.

Ve sledované skupině uvedlo $100 \%$ probandů dominantní PHK, dominanci PDK uvedlo 10 probandů (tj. $62,5 \%$ probandů) a dominanci LDK 6 probandů (tj. 37,5 \% probandů). Byl nalezen významný vztah dominance HK a DK k asymetrii tekutin na jednotlivých segmentech těla. I když všech 16 probandů, tj. 100 \%, uvedlo dominantní PHK, pouze u $14 \mathrm{z}$ nich (tj. 87,5 \%) se tato dominance projevila vyšší distribucí tekutin na PHK $(\mathrm{r}=0,732, \mathrm{p}<0,05)$. U 8 probandů (tj. $50 \%)$ se dominance PDK odrazila ve vyšší distribuci tekutin na PDK $(\mathrm{r}=0,524, \mathrm{p}<0,05)$. I přesto, že triatlon, resp. jeho jednotlivé disciplíny, patří mezi symetrické pohybové aktivity, můžeme pouze usuzovat, že př́íčinou těchto asymetrií tekutin na jednotlivých segmentech mohou být další vykonávané aktivity. Vztah dominance HK a DK k asymetrii v rozložení tělesných tekutin popisuje Hráský et al., (2009), asymetrii v rozložení tělesných tekutin na jednotlivých segmentech a př́padný vztah k pohybové aktivitě uvádí Skorocká et al., (2004), Malá et al., (2008, 2013). Distribuce tělesného tuku, konkrétně množství abdominálního tuku, jsou významným rizikovým faktorem. Je známo, že existují intersexuální rozdíly v množství a distribuci tělesného tuku. Tyto rozdíly jsou dány především hormonálně, muži ukládají více tuku do abdominální oblasti. Na množství a distribuci tělesného tuku se také v nemalé míře podílí i odlišná úroveň pohybové aktivity (Herland et al., 1998). Metodika BIA neumožňuje rozlišení podkožního a strukturálního tuku, je možné zjistit jen celkové zastoupení tělesného tuku (\%) v organismu. Množství tělesného tuku bylo u sledovaných jedinců v průměru $15,5 \pm 3,6 \%$, což odpovídá populačním normám. Literatura uvádí, že 
tukuprostá hmota je v lepším vztahu k úspěšnosti ve sportu (maximální aerobní výkon, čas běhu atd.) než procento tělesného tuku. Ukazuje se, že množství tukuprosté hmoty má na rozdíl od celkové tělesné hmotnosti, výšky a dalších morfologických ukazatelů úzký vztah k různým funkčním veličinám jako např. spotřeba $\mathrm{O}_{2} \mathrm{v}$ klidu a při práci, minutový srdeční objem, objem cirkulující krve, respirační objem atd. (Pařízková, 1977). Z řady studií obecně vyplývá, že hodnoty $\mathrm{VO}_{2}$ max klesají jednak se stoupajícím věkem a jednak v souvislosti s nárůstem tělesného tuku a úbytkem svalové hmoty. Úroveň maximální spotřeby kyslíku $\left(\mathrm{VO}_{2} \max \right)$ stanovené v testu na běhacím koberci $\left(57,4 \pm 7,1 \mathrm{ml} \cdot \mathrm{kg}^{-1} \cdot \mathrm{min}^{-1}\right.$, Tab. 2.) převyšují populační normy $\left(39,3 \mathrm{ml} \cdot \mathrm{kg}^{-1} \cdot \mathrm{min}^{-1}\right.$, Seliger \& Bartůněk, 1976, Máček \& Máčková, 1997) a odpovídají úrovni maximálního výkonu udávané u triatlonistů rekreační výkonnosti obdobného věku (56-58 ml. $\mathrm{kg}^{-1} \cdot \mathrm{min}^{-1}$, Holly et al., 1986, Slattery et al., 2006). Tukuprostou hmotu (FFM) lze také popsat za využití molekulárního modelu jako součet mimobuněčné hmoty $(\mathrm{ECM})$ a vnitrobuněčné hmoty $(\mathrm{BCM})$. Pro potřeby posouzení předpokladů pro pohybovou zátěž je rozhodující stanovení množství buněčné hmoty (BCM), která je částí tukuprosté hmoty (FFM) zahrnující metabolicky aktivní aerobní buňky kosterní a srdeční svaloviny, kostní tkáně a buňky vnitřních orgánů, patří mezi nejlepší ukazatele svalové činnosti, které mohou predikovat sportovní výkon (Andreoli et al., 2003, Bunc \& Skalská, 2011). Mimobuněčná hmota (ECM) je tvořena součtem extracelulární tekutiny $(\mathrm{ECW})$ a extracelulárních pevných látek (ECS). Z hlediska sportovního tréninku se jeví také velmi zajímavým parametrem poměr ECM/ BCM, který představuje kvalitativní charakteristiku kosterního svalu (Talurri et al., 1999). Nesprávná výživa je charakterizována sníženou hodnotou BCM, naopak velkým zvýšením ECM a zároveň normálními hodnotami tukuprosté hmoty (Shizgal, 1987).

Co se týká charakteru pohybové aktivity u sledovaného souboru, hlavní rozmanitost triatlonu spočívá především v rozdílné vzdálenosti $\mathrm{v}$ jednotlivých disciplínách, což vytváří specifické technické, fyziologické a nutriční aspekty pro sportovce (Bentley et al., 2008). Fyziologické změny, ke kterým dochází v průběhu tréninku či závodu, se prakticky odráží ve všech systémech těla a projeví se především v parametrech jako jsou aerobní kapacita (měřeno jako maximální spotřeba kyslíku, $\mathrm{VO}_{2} \mathrm{max}$ ), ekonomika pohybu (submaximální $\left.\mathrm{VO}_{2}\right)$ a frakční využití maximální kapacity $\left(\% \mathrm{VO}_{2} \max \right)$. Četné studie prokázaly poměrně vysoké průměrné hodnoty $\mathrm{VO}_{2}$ max u různých skupin triatlonistů, které jsou srovnatelné s hodnotami, které vykazují sportovci v jednotlivých vytrvalostních disciplínách a tyto hodnoty jsou jednoznačně vyšší než u netrénovaných jedinců (O’Toole \& Douglas, 1995). Přestože je tělesná zdatnost podmíněna geneticky, vhodným trénováním, cvičením a přiměřenou životosprávou je možné ji udržet i rozvíjet do konce života. Podle Měkoty \& Cubereka (2007) se zdatnost nevztahuje jen k fyzickému zatížení, ale je pojímána v souvislosti s požadavky denně prováděných činností, trávení volného času a možnosti participovat na širokém spektru pohybových aktivit. Fyzická zdatnost je tedy výsledkem stavu jejich jednotlivých komponent, kterými jsou silové schopnosti, hbitost, flexibilita, rovnováha a vytrvalost. Úroveň tělesné zdatnosti př́mo úměrně ovlivní výkonnost a funkční stav organismu. Funkční zdatnost každého člověka významně ovlivňuje dosavadní způsob života, jeho postoj k pohybu, fyzickým aktivitám (Spirduso, 2005). Pro udržení nebo obnovení tělesné zdatnosti, výkonnosti oběhového ústrojí a muskuloskeletálních funkcí je nutná dlouhodobá kontinuita přiměřené a adekvátní pohybové aktivity (celoživotní adherence $\mathrm{k}$ pohybu). Již za několik týdnů tělesné inaktivity dochází $\mathrm{k}$ ústupu téměř všech fyziologických ukazatelů tělesné zdatnosti. Optimální formou je dynamická svalová aktivita cyklického charakteru se zapojením co největší svalové hmoty, např. rychlá chůze, jogging, běh, plavání, pohyb na běžeckých lyžích, jízda na kole, aerobik a další formy společného cvičení s hudbou i bez ní, veslování, atd. (Bunc, 2006). Při posuzování vztahu $\mathrm{VO}_{2} \max \left(\mathrm{ml} \cdot \mathrm{kg}^{-1} \cdot \mathrm{min}^{-1}\right)$, resp. Vmax $\left(\mathrm{km} \cdot \mathrm{h}^{-1}\right.$, sklon 5 \%) a jednotlivých parametrů tělesného složení jsme však natolik významné vztahy nezjistili. Nejvýznamnější vztah byl mezi $\mathrm{VO}_{2}$ max a procentem tělesného tuku $(\mathrm{r}=-0,78, \mathrm{p}<0,05)$. Závislost $\mathrm{VO}_{2}$ max a ostatních parametrů tělesného složení se nepotvrdila $(\mathrm{r}=0,049-0,27, \mathrm{~N}$.S.). Dále byla zjištěna významná negativní závislost Vmax a procenta tělesného tuku $(\mathrm{r}=-0,534, \mathrm{p}<0,05)$, zatímco vztah Vmax $\mathrm{k}$ ostatním parametrům tělesného složení byl nevýznamný ( $\mathrm{r}=0,01-0,35$, N.S.). Studie (O’Toole \& Douglas, 1995) naznačuje, že konkurenční plavci mají lepší ekonomiku plavání než triatlonisti. Výsledky v jejich studii ukazují, že triatlonisti by se měli více zaměřit na zlepšení plavecké techniky. Kardiovaskulární, metabolické a neuromuskulární změny jsou hlavní fyziologické ukazatele lepší ekonomiky pohybu. Pravidelné cvičení snižuje psychický stres, zvyšuje sebedůvěru, aktivizuje postoje člověka k vlastnímu zdraví a pozitivně ovlivňuje životní návyky a výživu. Stimuluje mentální činnosti, snižuje výskyt depresí, úzkosti, přispívá k duševní svěžesti, zlepšení adaptace na stres, na pracovní zatížení i mimopracovní aktivity. Pohybová aktivita má velký význam při emocionálním ladění člověka. Cvičící člověk má zvýšený pocit důvěry ve své schopnosti (posílení sebedůvěry), snadněji rozptýlí obavy a stresy denního 
života. Pravidelná pohybová aktivita podporuje zvýšení pracovní kapacity, tj. podporuje psychické funkce (psychomotorika). Dochází k upravení abnormalit nálad, zmenšení depresí a neopodstatněných obav, kterými člověk může trpět (Bartůňková, 2006)

\section{ZÁVĚRY}

Existuje mnoho důvodů, proč se lidé pohybu nevěnují dostatečně. Jedním z nejčastěji uváděných je nedostatek času. Základní úroveň pohybové aktivity lze však včlenit do běžného života tak, že zabere skutečně minimum času, v některých případech jej dokonce může i ušetřit. Pohybová aktivita, především na kondiční úrovni, se stává kompenzací nedostatku pohybového zatížení a psychického tlaku jako důsledku současného způsobu života. Avšak v př́padě špatného kompenzačního programu může dojít k přetížení axiálních struktur jako důsledku unilaterální svalové hypertrofie, která může být další př́íčinnou axiální deviace na všech úrovních. V důsledku jednostranného přetěžování těla mohou vznikat funkční změny ve spinální oblasti, např́íklad ve formě funkčních spinálních bloků a funkční skoliózy. V případě opakovaného přetěžování může dojít také ke strukturálním změnám. Současný životní styl je charakterizován narůstajícím objemem volného času a současně je doprovázen výrazným poklesem pohybových aktivit. Dochází k poklesu fyzických nároků na organismus (hypoaktivita), které ustupují před nároky psychickými, a dále pak v souvislosti se stravovacími návyky může vzniknout nadbytek energetického př́ijmu. Pokles fyzických nároků a zvýšený energetický př́jem vede $\mathrm{k}$ poruchám regulačních systémů, přináší s sebou zdravotní rizika a vede k některým zdravotním poruchám, které mohou po čase vyústit do řady onemocnění, souhrnně nazývaných „civilizační choroby“. Ke vzniku některých z těchto onemocnění může být často zvýšená dědičná dispozice (Bunc, 2006). Vzájemné vztahy jednotlivých parametrů jsou výrazně ovlivněny individuální variabilitou daného jedince a nelze jednoznačně předpovídat jejich vývoj. Z hlediska diagnostiky lze z individuálních protokolů získaných př́stroji BIA, které umožňují segmentární analýzu, posoudit asymetrické rozložení tekutin na jednotlivých segmentech těla u jedince. Tato měření mohou doplnit kineziologický rozbor a poskytnout tak kompletnější informace o př́padných svalových dysbalancích (Skorocká et al., 2004). Lze říci, že analýza tělesného složení spolu s posouzením výstupním parametrů ze zátěžových testů jednoznačně dokresluje obraz o funkčním stavu organismu daného jedince. Dlouhodobé a pravidelné sledování změn tělesného složení a jejich závislost ke změnám v jednotlivých parametrech ze zátěžových testů může přinést významnou informaci o pozitivním či negativním vlivu životního stylu na organismus daného jedince.

\section{LITERATURA}

Andreoli, A., Melchiorri, G., Brozzi, M., Di Marco, A., Volpe, S.L., Garofano, P., Di Danikele, N. \& De Lorenzo, A. (2003) Effect of different sports on body cell mass in highly trained athletes. Acta diabetol., 40, p. 122-125. Bartůňková, S. (2006) Fyziologie člověka a tělesných cvičení. Učební texty Univerzity Karlovy v Praze. Praha: Karolinum, $285 \mathrm{~s}$.

Bassuk, S.S. \& Manson, J.E. (2005) Epidemiological evidence for the role of physical activity in recing risk of type 2 diabetes and cardiovascular disease. J Appl. Physiol., 99, p. 1193-1204

Bentley, D.J., Cox, G.R., Green, D. \& Laursen, P.B. (2008) Maximising performance in triathlon: applied physiological and nutritional aspects of elite and non-elite competitions. J. Sci. Med. Sport., 11 (4), p. 407-416. Bouchard, C. (2000) Physical activity and obesity. Champaign: Human Kinetics, 400 pp.

Bunc, V. (2006) Energetická náročnost pohybových aktivit a její využití pro ovlivňování tělesné hmotnosti. In Vobr, R. (ed). Disportare 2006. České Budějovice: Pedagogická fakulta Jihočeské univerzity

Bunc, V. (2007) Aktivní životní styl v biosociálním kontextu. Česká kinantropologie, 11 (3), s. 5-6.

Bunc, V. \& Skalská, M. (2011) Jsou předpoklady pro pohybové zatížení u osob s nadváhou nebo obezitou odlišné od osob s normální hmotností? Česká kinantropologie, 15 (3), s. 55-63.

Dlouhá, R., Heller, J., Bunc, V., Giampietro, M., Gambarara, D., AndreolI, A. \& Caldarone, G. (1998) Srovnání rovnic Pařízkové pro zjišt’ování tělesného tuku sportujících žen. Med. Sport. Boh. Slov., 7 (1), s. 7-12.

Herland, M. L., Haarbo, J. \& Christiansen, C. (1998) Regional body composition determined by dual energy $\mathrm{x}$-ray absorptiometry. Relation to trainung, sex hormones, and serum lipids in male long-distance runners. Scand J Med Sci Sports, 8, p. 102-108

Holly, R.G., Barnard, R.J., Rosenthal, M., Applegate, E. \& Pritikin, N. (1986) Triathlete characterisation and response to prolonged strenuous competition. Med Sci Sports Exerc, 18 (1), p. 123-127 
Hráský, P., Malý, T., Malá, L. \& Zahálka, F. (2009) Možnosti posouzení funkčního stavu pohybového aparátu u fotbalistů dorostenecké kategorie. Česká kinantropologie, 13 (3), s. 168-176.

Kichul, CH. et al. (1997) Segmental BIA for Determining Body Composition. Korean J. Community Nutrition, 2 (2), p. 179-186.

Kichul, CH. et al. (2001) Evaluation of Segmental BIA for Measuring Muscle Distribution. Research thesis based on In Body. Biospace.

Máček, m., Máčková, J. (1997) fyziologie tělesných cvičení. 1. Vyd. Brno: Masarykova univerzita, $112 \mathrm{~s}$.

Malá, L., Malý, T. \& Zahálka, F. (2008) Profil telesného zloženia juniorských reprezentantov v jude. Česká kinantropologie, 12 (3), s. 94-103.

Malá, L., Malý, T., Zahálka, F., Teplan, J. \& Kaplan, A. (2013) Kvalita aktívnej hmoty a segmentárna distribúcia tekutín v tele jako predpoklad výkonu u elitních basketbalistiek. Studia Sportiva, 7 (1), s. 15-21.

Měkota, K. \& Cuberek, R. (2007) Pohybové dovednosti - činnosti - výkony. 1. vyd. Olomouc: Univerzita Palackého v Olomouci. $163 \mathrm{~s}$.

O'Toole, ML. \& Douglas, PS. (1995) Applied physiology of triathlon. Sports Med., 19 (4), p. 251-267.

Pařízková, J. (1977) Body fat and physical fitness. Hague: Nijhoff, 279 s.

Pařízková, J. (1998) Složení těla, metody měření a využití ve výzkumu a lékařské praxi. Med. Sport. Boh. Slov., 7 (1), s. 1-6.

Roche, A.F., Heymsfield, S.B. \& Lohman, T.G. (1996) Human body composition. Champaign: Human Kinetics, $424 \mathrm{pp}$.

Seliger, V. \& Bartůněk, Z. (1976) Mean values of various indices of physical fitness in the investigation of Czechoslovak population aged 12-55 years. Prague, ČSTV

Shizgal, H.M. (1987) Nutritional assessment with body composition measurements. J Parenter Enteral Nutr., 11(5), p. $42-47$.

Skorocká, I., Bunc, V. \& Kinkorová, I. (2004) Určení distribuce tělesných tekutin př́ístrojem In Body 3.0. Česká kinantropologie, 8 (2), s. 19-25.

Slattery, K.M., Wallace, L.K., Murphy, A.J. \& Coutts, A.J. (2006) Physiological determinants of three-kilometer running performance in experienced triathletes. J Strength Cond Res, 20 (1), p. 47-52

Spirduso, W. W., Francis, K. L. \& MacRae, P. G. (2005) Physical dimensions of aging. Second ed. Human kinetics, $384 \mathrm{pp}$.

Stejskal, P. (2013) Proč a jak se zdravě hýbat. Břeclav: Presstempus, $125 \mathrm{~s}$.

Suriano, R. \& Bishop, D. (2010) Physiological attributes of triathletes. J. Sci. Med. Sport., 13 (3), p. 340-347.

Talluri, T., Lietdke, R. J., Evangelisti, A., Talluri, J. \& Maggia, G. (1999) Fat-free mass qualitative assessment with bioelectric impedance analysis (BIA). Ann N Y Acad Sci., 20 (873), p. 94-8.

Thomas, J.R. \& Nelson, J.K. (1999) Research methods in physical activity. Human Kinetics, USA 2001, 3th edition.

Wei, M., Kampert, J.B., Barlow, C.E., Nichaman, M.Z., Gibbons, L.W., Paffenbarger, R.S. \& Blair, S.N. (1999) Relationship between low cardiorespiratory fitness and mortality in normal-weight, overweight and obese men. Journal of the American Medical Association. 282, p. 1547-1553. 